\title{
NAZWY MIEJSCOWE JAKO ARTEFAKTY INSTYTUCJI PRAWNO-SPOŁECZNYCH MONARCHII WCZESNOPIASTOWSKIEJ
}

Słowa tematyczne: nazwy miejscowe, monarchia wczesnopiastowska, prawo książęce, instytucje prawno-społeczne, motywacja

\section{WSTĘP}

Przedmiotem artykułu są nazwy miejscowe będące artefaktami wybranych instytucji prawno-społecznych monarchii piastowskiej. Należą one do wczesnej warstwy nazewniczej, która była przedmiotem dociekań historyków od XIX wieku. Interesujące nas toponimy odegrały istotną rolę w badaniach nad organizacją państwa piastowskiego ${ }^{1}$. Nazwy własne posiadają określony status lingwistyczny i historyczny. W naukach historycznych posiadają rangę faktów historycznych (Topolski, 2009). Jako specyficzne znaki językowe odsyłają do konkretnych desygnatów - jednostkowych obiektów materialnych. W opisywanych toponimach zostały utrwalone instytucje związane $\mathrm{z}$ organizacją społeczną i prawem książęcym. Termin ten w naukach historycznych pojawił się dopiero w połowie XX wieku i odnosił się do szerokich uprawnień monarchii patrymonialnej, obejmujących takie obszary, jak władza sądownicza, administracyjna i gospodarka - powinności, pobieranie danin, świadczenie posług i korzystanie z regaliów (Modzelewski, 1987, s. 10-11). Został zapożyczony z trzynastowiecznych dokumentów, które potwierdzały rozkład i erozję tej instytucji. Prawo książęce stanowiło najważniejszy element ustrojowy monarchii wczesnopiastowskiej. Wszystkie założenia odnoszące się do jego istotnych elementów i sposobu funkcjonowania oparto na wnioskowaniu retrogresywnym i przyjęto pragmatycznie ze względu na małą liczbę zachowanych źródeł z wcześniejszego okresu. Informacje na temat danin i posług zostały pozyskane głównie z przywilejów

\footnotetext{
${ }^{1}$ Więcej na ten temat zob. Wójcik (2013, s. 11-13).
} 
immunitetowych. Na podstawie trzynastowiecznych źródeł odtworzono strukturę sądowo-administracyjną i organizację sąsiedzką ludności, która korzeniami sięgała bez wątpienia okresu plemiennego (Modzelewski, 1987, s. 14). Kwestią sporną pozostaje czas wykształcenia się uprawnień prawa książęcego. Część historyków wskazuje na same początki powstania monarchii (Modzelewski, 1987; 2000), inni datują ten proces na połowę XII wieku (Gawlas, 1996).

Trzeba podkreślić, że występowanie we wszystkich księstwach dzielnicowych identycznego zrębu instytucji prawno-społecznych przemawia za uznaniem prawa książęcego za spuściznę ustrojową monarchii pierwszych Piastów.

$\mathrm{W}$ toponimii polskiej odnajdujemy liczne poświadczenia i odwołania do nazw instytucji związanych z tym prawem. Wśród nich najliczniejszą grupę stanowią toponimy służebne związane z organizacją gospodarczą. Są one motywowane antroponimami zbiorowymi - nazwami służebników (Wójcik, 2013, s. 43-47). W przypadku tych osad mówi się o specyficznej sytuacji ,gospodarczo-osadniczego uniformizmu" (Modzelewski, 2000, s. 9), która doprowadziła do wykształcenia się określonego typu nazw. Osobną grupę tworzą toponimy utrwalające nazwy różnych kategorii wolnych chłopów. W monarchii piastowskiej przysługiwały im tzw. prawa grupowe. Wyznacznikiem przynależności do uprzywilejowanych grup było wyróżnienie i zdefiniowanie kategorialne przez nazwę. I tak w toponimii polskiej mamy potwierdzone następujące nazwy pozostające w związku z tą instytucją: Lazęki (: łazęcy), Rataje, na Śląsku — Oracze, Stróże i Dziedzice (Modzelewski, 1987, s. 103). Toponimy tego typu funkcjonowały w sytuacji dualizmu nazewniczego - desygnowały wyodrębnione w prawie książęcym grupy chłopskie (podstawowy desygnat) i osady przez nie zamieszkiwane. Proces toponimizacji tych antroponimów był czasowo skorelowany z erozją instytucji prawa książęcego. Moment utraty praw grupowych znosił potrzebę desygnowania gromad ludzkich. Onim na stałe związał się z jednym desygnatem — osadą. Czynniki pozajęzykowe wpłynęły na ostateczny kształt nazw. W klasyfikacjach onomastycznych wymienione toponimy są zaliczane do subkategorii nazw służebnych i zawodowych motywowanych antroponimami zbiorowymi.

Drugą i mniej liczną grupę tworzą nazwy miejscowe, które bezpośrednio były motywowane nazwami prawno-społecznych instytucji państwa pierwszych Piastów. Część z nich została odziedziczona po ustroju plemiennym i zaadaptowana na potrzeby monarchii patrymonialnej. W nazwach miejscowych Polski zostały przede wszystkim utrwalone określenia archaicznych powinności, które później zostały zastąpione daninami o takiej samej nazwie. Praktycznie nie ma w toponimach poświadczeń nazw powszechnych piastowskich danin, takich jak powołowe, poradlne, podymne, podworowe, narzaz i stan (Modzelewski, 1987, s. 66). W całym kraju pobierano te daniny w rozmaitych produktach (miód, zwierzęta, owies). Nazwy miejscowe utworzone od takich apelatywów mają charakter 
wieloznaczny i trudno wskazać jedną czytelną motywację. W artykule w porządku chronologicznym przybliżam wybrane instytucje monarchii wczesnopiastowskiej, które zostały spetryfikowane w średniowiecznych onimach.

\section{OPOLE}

Podstawową jednostkę organizacyjną społeczności plemiennej stanowiło opole. Był to związek sąsiedzki, którego instytucja utrzymała się również w Polsce piastowskiej. W dokumentach historycznych na jej określenie pojawia się łaciński termin vicinia. „Słownik staropolski” definiuje opole jako "jednostkę organizacji terytorialnej ludności chłopskiej, pewne ciężary publiczne i odpowiedzialność karną ponoszoną solidarnie przez tę ludność' (Sstp V 604). Jak podają mediewiści, w Małopolsce i na Śląsku używano również obocznej nazwy o(b)sada (Modzelewski, 1987, s. 32-34). Leksem opole kontynuuje psł. *o(b)pol'e, a to pochodzi od wyrażenia $o(b)+$ pol'e, w którym *pol'e oznaczało m.in. 'otwartą przestrzeń, równinę' SEBor 459, zapewne wśród lasów. Pojęcie to podkreślało terytorialny charakter związku, w przeciwieństwie do nazwy *o(b)sada, w której eksponowano wspólnotowość związku ludzi osadzonych na pewnym obszarze ${ }^{2}$. W średniowiecznych dokumentach związki opolne były określane najczęściej terminem łacińskim vicinia; kiedy odwoływano się do terytorium, używano formy districtus (Modzelewski, 1987, s. 34). Opola identyfikowano w dokumentach poprzez podanie w zapisie nazwy jego czoła (głównej miejscowości), np. vicinia de Wolborz (XIII w.). W toponimii polskiej mamy poświadczone nieliczne przypadki nominacji apelatywem opole. Zapewne były to główne miejscowości, w których zbierały się rady starszych i były prowadzone sprawy sądowe. Powstałe $\mathrm{w}$ wyniku onimizacji propria denotowały i indywidualizowały te jednostkowe byty. Utrwaleniu tych nazw pochodzenia odapelatywnego sprzyjało zapewne odejście od tej formy organizacyjnej państwa piastowskiego pod koniec średniowiecza, kiedy opola zostały włączone do kasztelanii (Modzelewski, 1987, s. 32-33). Zanik desygnatu $\mathrm{w}$ warstwie apelatywnej powodował zacieranie semantyki nazwy własnej.

Współcześnie na terenie Polski mamy potwierdzonych sześć miejscowości, których nazwy historycznie były motywowane apelatywem opole ${ }^{3}$ : Opole, mto wojewódzkie (Opul 1203); Opole, lub., gm. Podedwórze (Opole 1510); Opole, łódz., gm. Parzęczew (Opole 1396); Opole (dziś Stare i Nowe Opole, OpoleŚwierczyna), maz., gm. Siedlce (Opolye 1475); Opole, maz., gm. Radzymin

\footnotetext{
${ }^{2}$ O nazwach miejscowych z nagłosowym $o(b)$ - pisał P. Swoboda (2011).

${ }^{3}$ Wszystkie cytowane zapisy źródłowe pochodzą ze słownika „Nazwy miejscowe Polski. Historia. Pochodzenie. Zmiany" (dalej NMPol).
} 
(Opole 1827); Opole (od XX w. Opole Lubelskie), mto, lub. (de Opol 1325-27). W dokumentach historycznych potwierdzona jest jeszcze jedna — współcześnie nieistniejąca miejscowość — Opole, leżąca w Wielkopolsce w okolicach Kcyni (Opole 1136). Wydaje się, że najstarszą metrykę posiada śląski toponim śląski, to właśnie od niego utworzono nazwę tzw. małego plemienia - Opolanie. Została ona po raz pierwszy zapisana w formie Opolini w tzw. Geografie Bawarskim około 845 roku. Jest to adaptacja morfologiczna słowiańskiej nazwy na gruncie języka niemieckiego; sufiksem *-janie został oddany przez łac.-niem. -ini (Łuczyński, 2017, s. 85).

\section{PRZESIEKA, BRONA, STRÓŻA}

W nazewnictwie określającym daniny państwa piastowskiego znajdujemy liczną grupę terminów określających powinności związane z obronnością. Mediewiści wskazują tutaj na trzy podstawowe instytucje: przesiekę, bronę i stróżę, których rodowód sięga struktur plemiennych. Istotną rolę w systemie obronnym poszczególnych plemion odgrywała przesieka. Była to bariera zbudowana ze ściętych i poukładanych drzew. Wkoło tworzono obszary, na których obowiązywał zakaz karczunku i nowej kolonizacji. W przesiekach znajdowały się specjalne przejścia — brony, które były pilnowane przez stróży (Modzelewski, 1987, s. 39). Utrzymanie przesieki i obowiązek pilnowania bron oraz grodów przy przejściach w czasach plemiennych wykonywali naprzemiennie wszyscy mieszkańcy okolicy. Ta powinność była nazywana stróża. We wczesnym okresie monarchii piastowskiej obowiązkowe posługi zostały zmienione na odpowiednie daniny o takich samych nazwach. Powołano również specjalną kategorię ludności książęcej do obrony bron i grodów, zwaną stróżami (Buczek, 1957).

Nazwy wymienionych instytucji są dość dobrze utrwalone w toponimii polskiej. Historycy odnoszą do nich termin ,nazwy obronne” (Łowmiański, 1967, s. 98). Materiał toponomastyczny był wykorzystywany m.in. w badaniach organizacji obrony terytorialnej. Na szczególną uwagę zasługują prace Elżbiety Kowalczyk, której ustalenia w znacznym stopniu oparte są na danych toponomastycznych (Kowalczyk, 1992; 2000). Dużą grupę w obrębie tej kategorii semantycznej tworzą onimy motywowane ap. stróża. Pochodzi on od psł. *storža 'strzeżenie, pilnowanie kogoś lub czegoś, czuwanie, pełnienie nadzoru'. Nazwa czynności została utworzona od psł. *stergti, z sufiksem *-ja SEBor 580. Ta rodzima forma od XV wieku była wypierana przez zapożyczoną ze staroczeskiego stráž// strážě. W większości nazw miejscowych została przechowana pierwotna forma stróża. Na terenie Polski mamy poświadczenia kilkunastu toponimów związanych z tym etymonem, o następującym rozmieszczeniu: Stróża, część Rudnika nad Sanem, podkarp. (Wola Stróża 1662); Stróża, dlnśl., gm. Kąty Wrocławskie (de Strosa 1202); Stróża, łódz., gm. Andrespol, (Strosza 1511/12); Stróża, łódz., 
wś i os., gm. Rząśnia (Strossa 1386); Stróża, małopol., gm. Dobra (Stroza 1447); Stróża, małopol., gm. Pcim, Item ... strosam 1254; Stróża, święt., gm. Ożarów (Stroza 1783-84); Stróża, lub., gm. Kraśnik (Strocza 1325-27); Struża, lub., gm. Trawniki, (Stroza 1431); Straż, wś, podl., gm. Sokółka (Stróża 1548); Straża, wś, dlnśl., gm. Wołów (Strezsa 1414). Wymienione toponimy powstały zapewne w wyniku najprostszej konceptualizacji miejsca - nazwa powinności została przeniesiona na miejsce, w którym była ona pełniona. Być może znajdowały się tam małe grody strażnicze, które później dały początek nowym osadom o nazwie Stróża.

Termin stróża motywował również powstanie kilku formacji sufiksalnych, takich jak: Stróżów, dziś Strażów, podkarp., gm. Krasne (Stroszow 1436); Strożyszcze/Strożyska, dziś Strożyska, wś, święt., gm. Nowy Korczyn (de Strozicz 1325-27, Stroziska, Sthroziska 1370) i Stróżna, wś, małopol., gm. Bobowa (de stroschna 1378).

W wypadku kilku miejscowości o nazwie Stróżewo, uwzględniając kryterium topograficzne (położone przy dawnych przesiekach) i etymologiczne, należy również dopuścić możliwość motywacji odapelatywnej. Można tutaj wskazać na miejscowości z północnego Mazowsza, Wielkopolski, Kujaw i Pomorza: Stróżewo, gm. Załuski (Stroszewo, Strzozevo, Strozewo, Strozewo 1424); Stróżewo, gm. Dobrzyń nad Wisłą (Strozewo 1296); Stróżewo, gm. Chodzież (Stroszewo 1466); Stróżewo, gm. Piotrków Kujawski (Strosowo 1193); Stróżewo, gm. Pyrzyce (Ztrosewo, Strosow 1224). Trzeba podkreślić, że sufiksy -ow- / -ew-, -iszcze, -isko, -n- uzyskują dużą produktywność w nazwach odapelatywnych — topograficznych i kulturowych.

W toponimii polskiej mamy również utrwaloną nazwę Stróże, która denotuje kilka wsi na południu Polski — Stróże, małopol., gm. Grybów (Stroze 1288); Stróże, małopol., gm. Zakliczyn (Stroze 1369) i Stróże Małe i Wielkie, podkarp., gm. Sanok (Strosze 1439). W przypadku tych miejscowości możemy mówić o motywacji od antroponimu zbiorowego i identyfikacji miejsca zamieszkania poprzez nazwę określającą ich mieszkańców. Stróże zamieszkiwali obszary w pobliżu bron, których pilnowali, a więc w rejonie puszcz granicznych. Zostali wyodrębnieni nazwą w prawie książęcym i tworzyli osobną kategorię ludności chłopskiej pod względem prawnym. W związku z tym możemy założyć, że chronologiczne te nazwy są późniejsze od Stróży (powinność zachowana jeszcze $\mathrm{z}$ ustroju plemiennego).

Liczne ślady w nazewnictwie polskim pozostawił również apelatyw przesieka. „Słownik staropolski” podaje jego następujące znaczenia: "pas obronny powstały przez podcięcie i zwalenie drzew na pewnym odcinku; powinność polegająca na braniu udziału przy tworzeniu przesieki, pieniężny ekwiwalent tej powinności' (Sstp VII 23). W okresie plemiennym przesieki stanowiły granice między poszczególnymi plemionami, zabezpieczały przed napadami podczas 
międzyplemiennych walk i budowały poczucie odrębności (Modzelewski, 2000, s. 59-60). Powinność ta została przez monarchię odziedziczona i była wypełniana w ramach prawa książęcego. Wiązała się z utrzymaniem obronności kraju. Przesieki powstawały na rubieżach państwa piastowskiego.

Etymologicznie leksem zakotwiczony jest w prasłowiańszczyźnie, por. *sěkti 'ciąć ostrym narzędziem' SEBor 545 i przedrostek *per- 'prze-'. Zakres znaczeniowy tego leksemu ulegał rozszerzeniu od nazwy wytworu do nazwy instytucji prawnej - powinności, w końcowym etapie zamienionej na daninę. Podobnie przebiegał proces nominacyjny. Miejscowości, powstające w zalecanej odległości od przesieki, których mieszkańcy tworzyli i dbali o nią, przyjmowały nazwę Przesieka. Mamy też poświadczone formy derywowane sufiksalnie. Osady określane tym mianem są jedynym trwałym śladem najstarszej linii obronnej między plemionami lub rubieży państwa wczesnopiastowskiego. I tak mamy poświadczone z terenu całej Polski następujące nazwy miejscowe motywowane przez ap. przesieka (podaję tylko nazwy o średniowiecznej proweniencji): Przysieka, wś, małopol., gm. Kozłów (Przessek 1381); Przysieka, wś, wielkopol., gm. Śmigiel (Prisseca 1278); Przysieka, wś, wielkopol., gm. Wągrowiec (Preseca 1369); Przesieka, wś zaginiona, koło Gniezna (Preseca 1243); Przysieka, wielkopol., gm. Mieleszyn (Przeszieha 1272). W formie liczby mnogiej występują dwie miejscowości na południu Polski: Przysieki, wś, podkarp., gm. Skołyszyn (Preseky 1364), Przysieki, małopol., gm. Rzezawa (Priseki 1238).

Są też udokumentowane formy derywowane sufiksalnie: z sufiksem *-bn Przesieczna, wś, dlnśl. (Prseseczna 1300); z *-jb — Przesiecz, dziś Przysiecz, wś, opol., gm. Prószkow (Prissecz 1300); z sufiksem * -bsko — Przesieczsko, dziś Przysiersk, wś, kuj.- pom., gm. Bukowiec (Preseczsco 1328) i z sufiksem *_(bn)ica — dziś dwie wsi: Przysietnica, małopol., gm. Stary Sącz (Przisietnicza 1283), i Przysietnica, podkarp., gm. Brzozów (Przesiecznicza 1413). W XVI wieku w większości opisywanych nazw dochodzi do systemowej wymiany $e$ pochylonego w prefiksie prze- na przy-, stąd nowa forma Przysieka. Wcześniejsze trzynastowieczne zapisy nazw na przy- należy traktować jako wariant fonetyczny prze- $(<*$ per- $)$, a nie przy- $(<*$ pri- $)$.

Kolejną instytucją, której nazwa została spetryfikowana w toponimach, jest brona. W słownikach historycznych języka polskiego nie znajdujemy przywoływanego wcześniej znaczenia 'strzeżone przejście w przesiece' (Modzelewski, 1987, s. 39). Brona to wcześniejszy wariant bramy w znaczeniu 'strażnica'. Polska brona pochodzi od psł. *borna 'ochrona, osłona, obrona'. Jest to rzeczownik odczasownikowy od psł. *borniti 'bronić' SEBor 38. Od XVI wieku był zastępowany czeskim zapożyczeniem brána. Formy brama, też notowana broma z $m$, powstały w wyniku upodobnienia $n$ na odległość do dwuwargowego $b$. 
W toponimii odnajdujemy nieliczne ślady tego etymonu ${ }^{4}$. Można postawić hipotezę, że występujące na Pomorzu trzy nazwy Borne to pierwotne pom. *Barne (z wzdłużeniem $o$ do $a$ ), zaadaptowane do niemieckiego jako Borne. Na taki ślad wskazuje zapis z 1377 roku odnoszący się do miejscowości Borne w pobliżu Złocieńca. Autorzy NMP (I 292) przyjęli założenie, że zapis sugerujący odczytanie Barnim ( $a$ w miejsce $o$ ) jest zniekształcony. W związku z tym podano tylko jedno objaśnienie nazwy związane z niem. apelatywem Born ‘źródło'. Wydaje się zasadne wskazanie również potencjalnej możliwości motywacyjnej przez apelatyw brona w wypadku nazw z sufiksem -ow- (Bronów i Broniewo/Bronowo). Sufiks -ow- / -ew- derywował nazwy również od podstaw apelatywnych, tworząc toponimy o charakterze topograficznym i kulturowym. Być może pochodzą one od skróconej nazwy osobowej Bron/Broń, ale niewykluczony jest też związek $\mathrm{z}$ ap. brona. Trzeba podkreślić, że ta hipoteza została zanegowana w najnowszym opracowaniu historycznym poświęconym temu zagadnieniu (Kowalczyk, 2000, s. 16), przy czym autorka powołała się na słownik NMPol, który podaje wyłącznie w wypadku tych toponimów motywacje odantroponimiczne. Oprócz wymienionych dwuznacznych nazw o niepewnej motywacji możemy wskazać toponimy, które są motywowane tym leksemem. Są to nazwy następujących miejscowości: Bramka, wś, kuj.-pom., gm. Bukowiec — nazwa występowała początkowo w formach Bromka, Bronki (1412) i Branka (1526). Od XVI wieku ustala się współczesny wariant Bramka (1584). Zapisy nazwy dokumentują przeobrażenia fonetyczne rodzimego apelatywu bronka i ostateczne przyjęcie zapożyczenia czeskiego. Podobny rozwój nazwy, tożsamy z przekształceniami w sferze apelatywnej, obserwujemy w nazwach Bramka (Branka 1569) i Bramki (Branki 1432) z Mazowsza. W wypadku tej drugiej nazwy na uwagę zasługuje forma zestawiona Bramki Strasowe (1579), potwierdzająca związek z ap. stróża, później straż. Przywołane nazwy dotychczas nie były uwzględniane jako materiał egzemplifikacyjny w analizach historycznych.

Apelatyw brona stanowi również podstawę kilku innych derywatów sufiksalnych: Bronne (1325), z sufiksem *-bn-, dziś Branno, wś., kuj.-pom., gm. Gniewkowo; Bronne (1475), dziś Branno, wielkopol., gm. Rzgów. W przypadku tych nazw należy dopuścić związek etymologiczny z psł. rdzeniem *brbn-, ze względu na pojedyncze zapisy Brenna, wtedy w znaczeniu 'błotnisty, gliniany'. Poświadczoną mamy również formę Bronno (1386), dziś Bronno koło Łęczycy. Ostatni derywat sufiksalny to forma Brońsko (Bronska 1477), z sufiksem -bsk-, który głównie tworzył formacje odapelatywne. Wymieniona nazwa identyfikuje

${ }^{4} \mathrm{O}$ wykorzystaniu materiału toponimicznego w rekonstrukcji średniowiecznych bron pisze E. Kowalczyk (2000). 
wieś w Wielkopolsce koło Leszna. Zapisy historyczne onimów potwierdzają paralelne przekształcenia podstawy nazw i leksemu brona w okresie staropolskim. To przemawia za przyjęciem odapelatywnej motywacji wymienionych nazw miejscowości. W toponimii mamy zachowane również nazwy terenowe, których geneza nawiązuje do instytucji brony. Są to mikrotoponimy przedrostkowe Zabronie (Zabronie, część wsi Barcice, gm. Stary Sącz, i Zabronie, część miasta Zakliczyn), też poświadczone w materiale historycznym Zabronie koło Jasła (XIX w.) i Zabronie w okolicach wsi Barnowiec, gm. Łabowo (Kowalczyk, 2000, s. 18; Pawłowski, 1984, s. 227). Trzeba podkreślić, że właśnie na podstawie mikrotoponimów E. Kowalczyk (2000) próbowała odtworzyć lokalizację małopolskich bron.

\section{DZIESIĘTNE}

Kolejnymi toponimami w omawianej kategorii, które warto przybliżyć, są nazwy związane z tzw. organizacją setno-dziesiętniczą. Dotyczyła ona niewolników (jeńców i niewolnych chłopów), którzy byli osadzani w liczbie dziesięciu mężczyzn (najczęściej z rodzinami) na ziemi książęcej i traktowani jako jego osobista własność. W źródłach są określani łacińskim terminem decimi, nazwa staropolska to dziesiętne, por. stp. dziesiętny 'złożony z dziesięciu jednostek' (Sstp II 318), która odnosiła się do dziesięciu brańców. Niewolnicy byli osadzani w grupach, dziesiątka była podstawową jednostką większej zbiorowości zwanej setką, która podlegała nadzorowi książęcego setnika. Sama terminologia wskazuje już na rozbudowany system kontroli ludności niewolnej. Najwięcej osad zasiedlanych brańcami powstało w okresie rządów pierwszych Piastów w związku z podbojami sąsiednich ziem i ciągłym dopływem jeńców wojennych (Modzelewski, 1987, s. 118). W toponimii polskiej mamy dwa poświadczenia odwołujące się do tej instytucji prawnej. Są to najprawdopodobniej nazwy nowo założonych osad, którym dali początek brańcy. Jedna z nich to współcześnie część Lublina Dziesiąta (Deszanthe 1430). Drugi zapis źródłowy odnosi się do nieistniejącej już osady w okolicy Pobiedzisk w Wielkopolsce - Desente (1302). Na marginesie tych rozważań można dodać, że zapewne część toponimów zawierających w podstawie nazwę etniczną (typu Czechy, Prusy, Pomorzany) pierwotnie była związana z osadami brańców.

\section{NAROK}

„Słownik staropolski” definiuje narok jako ‘bliżej nieustaloną służebność dawnego prawa polskiego' (Sstp I 90). Nazwa tej powinności pochodzi od psł. 
*na-rekti 'przyrzec', też 'nazwać, określić, ustalić' i 'obwinić, uczynić zarzut'; to od psł. *rekti 'mówić, powiedzieć, nazwać' SEBor 353, 532. W staropolszczyźnie mamy potwierdzony czasownik narzec w podobnym znaczeniu 'powiedzieć, wymienić, oznaczyć', też 'przyganiać, postawić zarzut, potępić, oskarżyć o coś, zakwestionować coś' Sstp V 94. Począwszy od XIX wieku w historiografii polskiej odnajdujemy różne próby objaśnienia tej instytucji państwa piastowskiego. Od początku, z powodu braku odpowiedniej ilości zapisów źródłowych, stosowano kryterium filologiczne oparte na dociekaniach etymologicznych. Ustalenia etymologiczne z natury rzeczy cechuje różny stopień wiarygodności i prawdopodobieństwa. W wypadku nazw o przejrzystej semantyce etymologie nie nastręczają większych trudności. Oddziedziczony z zasobu prasłowiańskiego leksem narok miał charakter polisemiczny i powodował niejednoznaczne interpretacje dotyczące omawianej instytucji w prawie książęcym. Część historyków odwoływała się do pierwotnego znaczenia wyrazu związanego z przekazem ustnym. Inni odnosili się do nowszego znaczenia, mieszczącego się w obszarze prawnym. Najstarsze teorie dotyczące naroku były związane z kwestiami wojskowości (Wojciechowski, 1948, s. 96-99), następnie ewoluowały w stronę tzw. koncepcji służby informacyjno-łącznościowej (Pałucki, 1958). Narok miał być posługą pełnioną przez ministeriałów, polegającą na przekazywaniu wiadomości pomiędzy określonymi grodami. W związku z taką interpretacją w toponimii polskiej powinny być zachowane nazwy Naroczniki. Brak nazw motywowanych przez antroponim zbiorowy (służebnicy) narocznicy przemawia za odrzuceniem tej hipotezy. Równolegle próbowano połączyć genezę nazwy z instytucją prawną. Narok miał określać posiadłość skonfiskowaną w drodze postępowania karnego. Mieszkańcy, którym udowodniono przestępstwo, tracili wolność osobistą i popadali w zależność od najbliższego grodu (Bujak, 1925). Nie wchodząc w meandry rozważań historycznych, wypada podkreślić, że nazwa narok (por. znaczenia jej podstawy: 'przyrzec', 'ustalić') najprawdopodobniej odnosiła się do ziemi, która była uposażeniem grodów. Mieszkańców beneficjów nazywano narocznikami (Trawkowski, 1963). Sam etymon i jego znaczenie nie pozwala doprecyzować rodzaju i charakteru omawianej instytucji.

W toponimii polskiej mamy poświadczone trzy miejscowości, w tym jedną nieistniejącą, motywowane tym apelatywem: Narok (1511-23), zaginiona osada w pobliżu Kalisza; Narok, opol., gm. Dąbrowa (Naroci 1234, Narok 1499), i Naroków, dlnśl., gm. Wińsko (Narothowa ok. 1300, Narakow 1490). Pierwszy zapis w przypadku ostatniej miejscowości wyraźnie wskazuje, że pierwotnie mieliśmy do czynienia zapewne z formą zestawioną typu narokowa ziemia, narokowa osada. To raczej przemawia za koncepcjami odwołującymi się do podstawowego znaczenia, które później ewoluowało w stronę nazwy stanu prawnego. 


\section{UJAZD}

Kolejny interesujący nas termin, mający poświadczenia w toponimii, to ujazd. Słownik staropolski definiuje ujazd jako 'objazd lub obejście czyjejś posiadłości przez rozjemców w celu wytyczenia jej granic, rozgraniczenie nieruchomości' (Sstp IX 339). Jest to nazwa czynności pochodząca od psł. czasownika *jati, *jado 'jechać', z sufiksem -*zd(a) i prefiksem $u$ - SEBor 208. W monarchii piastowskiej ujazd jako akt prawny polegał na dokładnym wytyczeniu granicy sąsiadujących posiadłości. Likwidował on uprawnienia do zawłaszczania sąsiedzkich gruntów pod nowe uprawy. Sam ujazd nie znosił sąsiedzkich wspólnot pozostałych użytków takich jak pastwiska, lasy i dostępu do wód. Likwidowały je akty prawne zwane zapowiedziami (Modzelewski, 1987, s. 164). Praktyki ujazdów w dokumentach historycznych są potwierdzone od przełomu XII i XIII wieku. Wytyczanie granic było związane z kształtowaniem się tzw. władztwa gruntowego i poddaństwa ${ }^{5}$. Najczęściej było przeprowadzane na prośby Kościoła lub świeckich właścicieli związanych z dworem panującego. Decyzje podejmował książę, który często sam dokonywał objazdu w asyście przedstawicieli opola. Związek sąsiedzki był tu stroną szczególnie zainteresowaną, gdyż to jego członkowie tracili prawo do pozyskiwania nowych gruntów ornych w obrębie ujazdu. W nazewnictwie mamy zachowanych kilkadziesiąt potwierdzeń tej piastowskiej instytucji prawnej. Pochodzą z całego obszaru monarchii Piastów i z reguły mają bardzo stare poświadczenia. Możemy przyjąć, że miejscowości, których nazwy są motywowane tym apelatywem, powstawały w posiadłościach kościelnych czy też możnowładców bezpośrednio po wytyczeniu ich granic. Toponimy dokumentują w sposób bezpośredni stan prawny ziem, na których były lokowane nowe miejscowości. Najczęściej występuje forma $\mathrm{Ujazd}$, która identyfikuje ponad 20 miejscowości w Polsce. Najstarsze potwierdzenia pochodzą z końca XIII wieku i dotyczą wsi Ujazd w gm. Iwaniska w woj. świętokrzyskim — Uiazd 1174. Większość poświadczeń przypada na XIII i XIV wiek, np. małopolski Ujazd w gm. Kołaczyce - Uiazd 1288.

Interesujący nas termin został również utrwalony w formach sufiksalnych, takich jak Ujazdów (warszawski Ujazdów - Iazdow 1282), Ujazdowo (koło Ciechanowa - Vyasdovo 1403), Ujeździec (dwie miejscowości na Śląsku) i też wtórnie Ujeźdzce, dziś Ujejsce, koło Będzina (Ugyesdzecz $1443 \rightarrow$ Ujeysce XVIII w.). W przypadku jednej miejscowości mamy zachowaną nazwę z sufiksem -na: Ujezdna koło Przeworska (Vyesdna 1446). W mikrotoponimii spotykamy

${ }^{5}$ Władztwo gruntowe polegało m.in. na zwierzchnim prawie własności do chłopskiej ziemi, przede wszystkim księcia (prawo książęce), później zostało rozciągnięte na całość władzy pańskiej. W ramach tego władztwa chłopów łączył z panem gruntowym stosunek zależności o charakterze wieczystego poddaństwa (Modzelewski, 2000, s.172). 
również formy derywowane paradygmatycznie — w liczbie mnogiej Ujazdy. W toponimii Śląska Opolskiego została przechowana nazwa z synonimiczną formą objazd: Obes 1288 (dziś Objazda). „Słownik staropolski” definiuje termin objazd jako: '1. okręg, obwód, regio, tractus; 2. teren objęty jurysdykcją biskupa, diecezja' (V 339-340). Podane znaczenia sugerują, że przywołany toponim określał pierwotnie wydzieloną własność biskupią.

\section{LGOTA, WOLA}

Liczną grupę nazw w toponimii polskiej tworzą nazwy odwołujące się bezpośrednio do procesów kolonizacyjnych, takie jak Lgota/Ligota, Wola i formy pochodne, Korzeń (osady powstałe na surowym korzeniu). Zorganizowana kolonizacja w Polsce piastowskiej rozpoczęła się od tzw. obyczaju wolnych gości (hospites) i jest ona nazywana kolonizacją na prawie polskim. Okres kolonizacyjny zamyka ramy czasowe funkcjonowania instytucji prawa książęcego. Ten typ osadnictwa nie pozostawił śladów w polskim nazewnictwie (Modzelewski, 2000, s. 153, 215). Od końca XII wieku podejmowano na ziemiach polskich zorganizowane akcje osiedlania kolonistów pochodzenia walońskiego, flamandzkiego, a zwłaszcza niemieckiego. Od czasów Henryka Brodatego (ok. 1170-1238) mówi się o znacznej intensyfikacji procesu osadniczego. Okres kolonizacyjny oznacza koniec funkcjonowania archaicznych instytucji prawa książęcego. Przyciągnięcie wolnych osadników wymagało stworzenia korzystnych warunków lokacji nowych wsi. Przybysze przede wszystkim zyskiwali przywilej posługiwania się własnym prawem (tzw. prawo niemieckie), nabywali dziedziczne lenno chłopskie, wolność osobistą, w zamian byli zobowiązani do płacenia umiarkowanego czynszu. Wszystkie ulgi przeznaczone były dla imigrantów, a nie dla rodzimych chłopów, którzy podlegali zwierzchności księcia lub pana gruntowego i byli zobowiązani do regularnych świadczeń na rzecz monarchii. Chodziło o utrzymanie dotychczasowych zasad prawa książęcego w stosunku do autochtonicznej ludności. Potencjał przybyszów nie zapewniał rosnących potrzeb rodzącej się klasy feudalnej. W związku z tym do kolonizacji została dopuszczona ludność miejscowa. Kolonizacja wewnętrzna przebiegała na zupełnie innych zasadach, obowiązywał niepełny immunitet ekonomiczny, polegający na ulgach w świadczeniach przewidzianych w prawie książęcym. Akcja zakładania takich osad została zainicjowana na początku XIII w. na Śląsku przez Henryka Brodatego, później była kontynuowana (z mniejszą intensywnością) w innych ziemiach dzielnicowych, włączanych do odbudowywanej monarchii. Specjalny status takich rodzimych osad określano terminem lgota w znaczeniu 'ulga' (Modzelewski, 1987, s. 246-247). Wyróżniał on uprzywilejowaną osadę, niosąc istotne informacje społeczno-gospodarcze. Spełniał kryterium indywidualizacji obiektu i bardzo 
często dawał początek nazwie miejscowej. Powstawanie tego typu osad było ograniczone w czasie i przestrzeni. Segregacja osadnicza na dłuższą metę była nie do pogodzenia z interesami możnowładców, dlatego po uzyskaniu zezwolenia na lokację ze stosownym immunitetem mogli oni osadzać wolnych chłopów w nowo tworzonych osadach na prawie niemieckim (połowa XIII wieku). Na samym Śląsku w tym czasie powstało około 90 miejscowości noszących nazwę Lgota, prawie połowa z nich przetrwała do dzisiaj (Modzelewski, 1987, s. 248). Obecnie toponim Lgota identyfikuje miejscowości na Śląsku, w historycznej południowej Małopolsce i w Wielkopolsce. Osady te, jak podkreślają historycy, zyskały pełny immunitet ekonomiczny z chwilą zrównania w prawie osadników niemieckich i polskich. Zostały jednakże przy starych, utrwalonych nazwach w opozycji do nowo lokowanych polskich wsi na prawie niemieckim, które w nazwie przybierały określenie wola. Trzeba zauważyć, że równolegle przebiegała kolonizacja niemiecka, a przybysze wprowadzali do nazewnictwa polskiego obce elementy. W procesie nominacyjnym zakładanych osad odwoływali się do swojego pochodzenia, języka i kultury (Czopek, 1995).

W piśmiennictwie onomastycznym utrwalił się pogląd, że formy Lgota i Ligota są charakterystyczne dla dialektu śląskiego i synonimiczne z nazwami Wola, występującymi na pozostałym obszarze Polski (Taszycki, 1958, s. 312-313). Witold Taszycki wyprowadził ten wniosek na podstawie kryterium terytorialnego i porównawczego. Odwołał się do czeskiego materiału toponomastycznego, w którym występują liczne potwierdzenia nazw miejscowych motywowanych apelatywem lhota (według wyliczeń autora - około 300). Trzeba podkreślić, że w podobnym czasie w monarchii Przemysława Ottokara I była prowadzona intensywna akcja osiedleńcza, przede wszystkim na czeskim południowym Przedgórzu Sudeckim. Zaczęto wycinać graniczną Przesiekę Śląską i rozciągający się wzdłuż niej las. Intensywna kolonizacja po stronie czeskiej była prawdopodobnie głównym impulsem do przeprowadzenia podobnej akcji na polskim Śląsku. Nie jesteśmy w stanie współcześnie rozstrzygnąć, czy doszło do zapożyczenia terminu osadniczego przez dwór Henryka Brodatego (Zientara, 1975, s. 46-50, 180). Sam apelatyw lgota (czes. lhota) pochodzi od psł. *lbgъ 'lekki', z sufiksem *-ota (por. SEBor 292). Według Taszyckiego forma Ligota powstała, i to dość późno, na gruncie dialektu śląskiego. Miejscowości leżące poza Śląskiem w większości utrzymały nazwy Lgota (16 miejscowości), ale mamy też przykłady z nagłosowym $L i$ - (7), trzeba jednakże podkreślić, że są to innowacje późne, przeprowadzone w XIX wieku. Brak uwzględnienia zarysowanego wcześniej kontekstu historycznego doprowadził w tym przypadku do błędnych wniosków końcowych. Instytucja prawna lgota jako instytucja prawna miała ograniczony zasięg czasowy (pierwsza połowa XIII wie$\mathrm{ku}) \mathrm{i}$ terytorialny (monarchia Henryka Brodatego), dlatego nie rozprzestrzeniła się na pozostałe dzielnice rozbitego państwa piastowskiego. Współcześnie mamy 
poświadczone 23 obiekty o nazwie Lgota/Ligota poza historycznym Śląskiem, dokumentują one inkorporowanie poszczególnych dzielnic do restaurowanej monarchii. Na samym Śląsku zachowało się prawie 40 toponimów, zdecydowana większość to nazwy zestawione (34). W przypadku trzech wsi, które w średniowieczu były w dokumentach określane mianem Lgota, po 1945 roku urzędowo wprowadzono nazwę Lgotka. Najstarsze potwierdzenia nazw miejscowości pochodzą z trzeciego dziesięciolecia XIII wieku i występują w aktach lokacyjnych: apud Lgotam 1228 (Lgota, śl., gm. Rudnik, koło Raciborza), Lgotam 1228 (Lgota, opol., gm. Polska Cerkiew, koło Kędzierzyna-Koźla). W Wielkopolsce mamy zachowaną oboczną jednostkową nazwę derywowaną od tego samego etymonu z sufiksem -ów: Lgow 1391 (Lgów koło Żerkowa).

\section{PODSUMOWANIE}

Niniejszy artykuł wyrasta z tradycji onomastyki historyczno-etymologicznej, która zawsze miała charakter interdyscyplinarny. Przedmiotem opisu w artykule były toponimy, w których zostały spetryfikowane nazwy instytucji prawno-społecznych monarchii wczesnopiastowskiej. Prawidłowe objaśnienie tych nazw implikuje wykorzystanie wiedzy historycznej i odpowiedniej metodologii badawczej. Rozszerzenie językoznawczej perspektywy opisu o znajomość kontekstu historycznego i odtwarzanej konsytuacji nazewniczej umożliwia nową interpretację i wyjaśnia związki między formą, pierwotnym znaczeniem i funkcją opisywanych nazw własnych. Opisywane nazwy miejscowe powstawały jako jednostki językowo znaczące i przejrzyste semantycznie ze względu na swoje odwołania do instytucji prawa książęcego. Zanik desygnatów w płaszczyźnie apelatywnej (likwidacja instytucji) spowodował, że już w okresie staropolskim określenia te wyszły z użycia w języku ogólnym. Interesujące nas toponimy wraz z osadami, które denotują, są jedyną materialną pozostałością przywoływanych instytucji. Współcześnie tworzą one „archiwum kulturowe” państwa piastowskiego.

\section{LITERATURA}

Bednarczuk, L. (2018). Poczatki i pogranicza polszczyzny [The Beginnings and Borderlands of Polish]. Kraków: Lexis.

Buczek, K. (1957). Stróże. Studium z ustroju społecznego Polski wczesnofeudalnej [Stróże. A study of the social system of early feudal Poland]. Roczniki Dziejów Spolecznych i Gospodarczych, $19,11-41$.

Bujak, F. (1925). Narok. Przyczynek do ustroju społecznego Polski piastowskiej [Narok. Contribution to the Social System of Piast Poland]. Badania z Dziejów Spolecznych i Gospodarczych [Research on Social and Economic History] (z. 1). Lwów: Instytut Popierania Polskiej Twórczości Naukowej. 
Czopek-Kopciuch, B. (1995). Adaptacje niemieckich nazw miejscowych w Polsce [Adaptations of German Place Names in Poland]. Kraków: Instytut Języka Polskiego PAN.

Gawlas, S. (1996). O ksztalt zjednoczonego królestwa. Niemieckie wladztwo terytorialne a geneza spolecznoustrojowej odrębności Polski [For the Shape of a United Kingdom. German Territorial Sovereignty and the Roots of Poland's Socio-Political Identity]. Warszawa: DiG.

Hensel, W. i Pazdur, J. (red.). (1978). Historia kultury materialnej Polski w zarysie [History of Polish Material Culture] (t. 1-6). Wrocław: Zakład Narodowy im. Ossolińskich.

Kowalczyk, E. (1992). „Nazwy obronne” Stup, Samborza i Zawada a zagadnienie obrony stałej ziem polskich w średniowieczu [,,Defensive Names” Stup, Samborza and Zawada and the Problem of Permanent Defense of Polish Lands in the Middle Ages]. Warszawa: Instytut Archeologii UW.

Kow alczyk, E. (2000). Brona Małopolska. Ze studiów nad obrona stała ziem polskich we wczesnym średniowieczu [Brona Małopolska: From Studies on Permanent Defense of Polish Lands in the Early Middle Ages]. Warszawa: Instytut Archeologii UW.

Łowmiański, H. (1967). Początki Polski. Z dziejów Stowian w I tysiącleciu n.e. [The Beginnings of Poland. From the History of the Slavs in the First Millennium CE] (t. 3). Warszawa: PWN.

Łuczyński, M. (2017). „Geograf Bawarski” — nowe odczytania [„Bavarian Geographer” — revisited]. Polonica, 37, 67-89.

Modzelewski, K. (1987). Chtopi w monarchii wczesnopiastowskiej [Peasants in the Early Piast Monarchy]. Wrocław: Zakład Narodowy im. Ossolińskich.

Modzelewski, K. (2000). Organizacja gospodarcza państwa piastowskiego [Economic Organization of the Piast State]. Wrocław: Zakład Narodowy im. Ossolińskich.

NMPol = Rymut, K. i in. (red.). (1996-2018). Nazwy miejscowe Polski. Historia. Pochodzenie. Zmiany [Place Names of Poland. History. Origin. Changes] (t. 1-15). Kraków: IJP PAN.

Pawłow ski, E. (1984). Nazwy terenowe ziemi sadeckiej [Field Names of the Land of Nowy Sacz]. Wrocław: Zakład Narodowy im. Ossolińskich.

Pałucki, W. (1958). Narok. Studium z dziejów stużby informacyjno-łącznikowej w Polsce wczesnośredniowiecznej [Narok. A Study of the History of the Information and Liaison Service in Early Medieval Poland]. Wrocław: Zakład Narodowy im. Ossolińskich.

SEBań = Bańkowski, A. (2000). Etymologiczny stownik języka polskiego [Etymological Dictionary of the Polish Language] (t. 1-2). Warszawa: PWN.

SEBor = Boryś, W. (2005). Stownik etymologiczny języka polskiego [Etymological Dictionary of the Polish Language]. Kraków: Wydawnictwo Literackie.

Sstp = Urbańczyk, S. i in. (red.). (1953-2002). Stownik staropolski [The Old Polish Dictionary] (t. 1-10). Wrocław: Zakład Narodowy im. Ossolińskich-Instytut Języka Polskiego PAN.

Swoboda, P. (2011). O kilku polskich toponimach z nagłosowym $o(b)$ - na tle słowiańskim [On several Polish toponyms with initial $o(b)$ - against a Slavic background]. Onomastica, 55, 53-71.

Taszycki, W. (1958). Śląskie nazwy miejscowe [Silesian place names]. W: W. Taszycki (red.), Rozprawy i studia polonistyczne [Polish Dissertations and Studies] (t. 1, s. 297-320). Wrocław: Zakład Narodowy im. Ossolińskich.

Trawkowski, S. (1963). Narok — beneficjum [Narok — the benefice]. Kwartalnik Historyczny, $70(2), 437-439$.

Wojciechowski, T. (1948). Państwo polskie w wiekach średnich. Dzieje ustroju [The Polish State in the Middle Ages. The History of the System] (wyd. 2). Poznań: Księgarnia Akademicka.

Wójcik, U. (2013). Polskie toponimy zwiazane z organizacja gospodarcza państwa wczesnopiastowskiego. Nazwy miejscowe motywowane antroponimami zbiorowymi [Polish Toponyms Related to the Economic Organization of the Polish Kingdom Under the Early Piast Dynasty. Place Names Motivated by Collective Anthroponyms]. Kraków: Lexis.

Zientara, B. (1975). Henryk Brodaty i jego czasy [Henryk Brodaty and His Times]. Wrocław: Zakład Narodowy im. Ossolińskich. 


\section{SUMMARY}

\section{PLACE NAMES AS ARTIFACTS OF LEGAL AND SOCIAL INSTITUTIONS OF THE EARLY PIAST MONARCHY}

The article focuses on toponyms genetically related to the princely law in the Piast monarchy. Historical terms (opole, przesieka, brona, stróża, stróże, dziesiętne, ujazd, lgota) have been recorded in them. The correct explanation of these names implies the use of historical knowledge and appropriate research methodology. The extension of the linguistic perspective of description with the knowledge of the historical context and the reconstructed onyms enables a new interpretation and explains the relations between the form, original meaning and function of the described proper names.

Keywords: toponyms, early Piast monarchy, princely law, legal and social institutions, motivation 